\title{
Unhu/Ubuntu and Education for Reconciliation in Zimbabwe
}

\author{
Oswell Hapanyengwi-Chemhuru \\ University of Zimbabwe \\ E-mail: oswell_tap@yahoo.com
}

Edward Shizha

Wilfrid Laurier University, Brantford

E-mail: eshizha@wlu.ca

\begin{abstract}
The paper examines the concept, strengths and shortcomings, role and implementation of the reconciliation policy as Zimbabwe emerged from periods of conflict crisis soon after independence in the 1980s, and the current crisis in the 2000s and how the policy can be introduced in schools through 'education for reconciliation'. The authors argue that education can be used to cultivate reconciliation and national healing in the evidently 'wounded' people of Zimbabwe who bear scars of colonial times and war, and the post-independence conflicts. Reconciliation through education for "diversity" and tolerance makes a compelling argument in so far as we understand how education shapes culture and cultivates values among a people. Education for reconciliation is perceived as a philosophy that promotes respect for human life and human dignity. The paper concludes that education is an instrument for the inculcation and promotion of the epistemic and ontological principles enshrined in the African philosophy of Ubuntu/unhu.
\end{abstract}

\section{Introduction}

When Zimbabwe attained independence on April 16, 1980, the then new Prime Minister, Robert Gabriel Mugabe proclaimed a policy of National Reconciliation between the forces that had been fighting during the liberation war. According to Machakanja (2010), one of the daunting tasks faced by a society left in ruin after a period of political unrest or crisis is the rebuilding of that society. That the policy of National Reconciliation has not been as successful in Zimbabwe as was envisaged needs no special justification. Mugabe himself, the architect of the policy in Zimbabwe is of the belief and opinion that the policy of National Reconciliation in as far as it was extended to people of Occidental origins in Zimbabwe, was not reciprocated. However, the Government of Zimbabwe under Mugabe's Zimbabwe African National Union Patriotic Front (ZANU-PF) is accused of being disingenuous in its proclamation of reconciliation as later political and economic policies implemented until recent years reveal. When the policy was enunciated, the parties to the reconciliation process were not only Africans and Europeans, but also African to African given the diversity of political parties and opinions extant in Zimbabwe at independence and the 'regional conflict' that was ended by the Unity Agreement of 1987. This paper examines the concept, role and implementation of reconciliation policy as Zimbabwe emerged from a conflict crisis in the early 1980s and how the reconciliation policy can be introduced in schools through 'education for reconciliation'. Education for reconciliation and Ubuntu/Unhu are perceived as philosophies that promote respect for human life and human dignity and values that give meaning to people's lives and livelihoods. The paper concludes that education comes in as 
an instrument for the inculcation and promotion of the epistemic and ontological principles enshrined in the African philosophy of Ubuntu/unhu.

\section{Reflecting on the Meaning of Reconciliation}

Despite growing academic and political attention, the concept of reconciliation is as yet inadequately explored (Loizides, Kovras \& Ireton, 2011). For one thing, there is no universally agreed-upon definition. Mawondo (2009, p.3) defines reconciliation as "a process that re-establishes love and understanding between two or more estranged parties." $\mathrm{He}$ further argues that what is important is that the initial cause of the problem must be honestly reappraised with a view to finding a genuine solution. Reconciliation requires that all parties to the conflict must present their demands and that any proposed settlement should take into account these various demands. Reconciliation involves self-appraisal, negotiation and compromise. The argument for compromise and leniency rests on the need to achieve reconciliation so that a conflict situation is resolved and a new democracy emerges based on tolerance, broad-mindedness and accommodation of differences and diversity. For Luc Huyse 2005, p. 8), "Reconciliation prevents, once and for all, the use of the past as the seed of a new conflict. It consolidates peace, breaks the cycle of violence and strengthens newly established democratic institutions."

The most frequently cited definition of reconciliation is from the Institute for Democracy and Electoral Assistance (IDEA) in the United States, which states, "Reconciliation is an overarching process that includes the key instruments of justice, truth, healing, and reparation for moving from a divided past to a shared future" (2003, p. 4). Reconciliation therefore seeks to reconnect, to re-establish the harmony disturbed or destroyed by the conflict through arriving at a common understanding. This further implies that genuine reconciliation is always mutual. It, therefore, follows that reconciliation by its very nature involves a willingness to sacrifice, to be accommodative of each other's demands and expectations. All parties to the negotiation must feel that their concerns have been addressed if the ensuing reconciliation is to endure. Therefore, in the aftermath of the cessation of hostilities, the objective is no longer merely negative peace - or the absence of violence - but social transformation that will eventually restore broken social bonds and reinstate collapsed institutions (Loizides et al., 2011). In this dual normative context, the concept of reconciliation is a central goal of peace building.

Scholars from different disciplines tend to investigate different aspects of reconciliation, focussing on different actors, adopting different instruments, and ultimately subscribing to different definitions of reconciliation, thereby leading to what could be called "a dialogue of the deaf" (Loizides et al., 2011, p. 5). There is no agreement on models that are used to describe reconciliation. However, Mawondo (2009, p. 3) identifies two models of reconciliation (a) reconciliation with justice, and (b) reconciliation without justice. He argues that reconciliation without justice is bound to fail because it leaves structures of injustice in place and it ignores the causes of the conflict. Since most wars are fought in the name of justice, reconciliation cannot succeed until justice is done. Consequently, Mawondo advocates the adoption of reconciliation with justice. Machakanja (2010) brings into the argument the concept of transitional justice for reconciliation. She argues that although the concept of transitional justice remains contested in meaning and form, it is usually associated with a wide range of processes and mechanisms that underpin a society's attempts to come to terms with a legacy of violent past abuses. Thoms, Ron and Paris (2008) say:

Transitional justice mechanisms include trials and other judicial proceedings against individuals alleged to have committed gross violations of human rights; truth 
commissions designed to establish a factual historical record of past wrongdoing; reparations to victims of past abuses; and vetting of individuals to determine if their past activities or affiliations render them ineligible for public office, law enforcement or other key roles. (p. 4)

In Zimbabwe, after a decade of gross human rights violations and the atrocities of the early 1980s, and the political violence between 2000 and 2009, people are generally agreed that Zimbabwe needs a transitional justice system and a truth and reconciliation process that guarantee maximum accountability for committed atrocities to facilitate sustainable national healing and peace (Machakanja, 2010). Reconciliation that involves transitional justice would fit well with the model of reconciliation with justice.

Van Binsbergen (1999, p. 3) views the reconciliation process as "a creative social act of rearrangement and re-interpretation" and the "transformation of conflict" into peace. Reconciliation involves or leads to the reorientation of the everyday life of all group members concerned. It is both a concrete moment and a process which once initiated needs to be sustained. This means that reconciliation requires cooperation of the parties involved in the creation of a new dispensation. Subsequently, this implies the adoption of a shared vision for a collective destiny. Overall, the necessary condition for reconciliation is the recognition by the parties concerned that there is a specific and explicitly expressed conflict that needs to be resolved. Van Binsbergen (1999) argues:

Reconciliation is only possible if the conflict is clearly and publicly discussed by those involved, and such discussion creates a clarity which may well have a beneficial influence on future relations, also because previously unexpressed contradictions have found an overt formulation which allows them to be taken into account much more readily in the social process. (p. 3)

So there is need for openness about the cause of the conflict, clarity about what is at stake and a willingness to work for the benefit of all.

\section{The Policy of Reconciliation in Zimbabwe}

Since the beginning of the third millennium, Zimbabwe has moved from being a model of racial reconciliation in a post-guerrilla-war context to receiving widespread condemnation as a result of ZANU-PF's repudiation of reconciliatory politics (Raftopoulos, 2004). The history of Zimbabwe is characterised by a series of challenges which, at different turning points, manifested themselves through violent conflicts. Since attaining independence, the issue of achieving sustainable peace and development has remained a challenge due to human rights violations (Machakanja, 2010). However, in 1980, after the war of liberation, Mugabe called for amity among Africans and between Africans and Europeans, urging the populace to forgive and forget the past (de Waal, 1990). Realising that the peace that came through the attainment of sovereignty set the stage for the process of National Reconciliation, he called upon the people of Zimbabwe to build a new nation together. However, the adoption of the policy of National Reconciliation was an act of great sacrifice on the part of the African majority. It was great sacrifice in that the Lancaster House Agreement that ended the war was crafted in such a way that the redistribution of land, the main cause of the war could only effectively take place after ten years of independence. Before then land could only be secured on a willing seller willing buyer principle.

There are disagreements over whether political transitions genuinely require a unique type of justice - such as the one that emphasises reconciliation as opposed to retributive 
justice - or a compromise of the two options (Graybill, 2002). Nonetheless, Mugabe proclaimed the policy of National Reconciliation thus:

Surely this is now the time to beat our ploughshares so we can attend to the problems of developing our economy and our society... I urge you, whether you are African or European, to join me in a new pledge to forget our grim past, forgive others and forget, join hands in a new amity, and together, as Zimbabweans, trample upon racialism, tribalism and regionalism, and work hard to reconstruct and rehabilitate our society as we reinvigorate our economic machinery. (de Waal, 1990, p. 46)

This appears to have been an attempt to unite the people of Zimbabwe into sharing a common destiny, a common vision aimed at the development of Zimbabwe. The call gives the impression that it was directed at all people in Zimbabwe, Africans and Europeans. Yet, when it came to Africans, it was selectively applied as the forgetting and forgiving seem to have been withheld in the case of some Africans. At the same time, problems were bound to arise in the realisation of the policy of National Reconciliation for how could the past be forgiven and forgotten without the people first coming to terms with the past. Much more than just the enunciation of the policy of reconciliation was needed. Mugabe continued to plead for solidarity when he urged:

Finally, I wish to assure all the people that my government will strive to bring about meaningful change to their lives. But everyone should exercise patience, for change cannot occur overnight. For now, let us be united in our endeavour to lead the country to independence. Let us constitute oneness derived from our common objective and total commitment to build a great Zimbabwe that will be the pride of all Africa. Let us deepen our sense of belonging and engender a common interest that knows no race, colour or creed. Let us truly become Zimbabweans with a single loyalty. (de Waal, 1990, p. 47)

In this case there was the realisation of the importance of national unity for without this, the policy of National Reconciliation was bound to fail. But also assumed here are the desires and commitments of all citizens to work together in order to share a common destiny and vision. But was there such a common vision? It is perhaps proper to interpret the above as an invitation to all Zimbabweans to participate in the development of the country in unison. Impediments to the acceptance of this invitation were already present in the form of the socialist ideology that the new government enunciated.

Socialism was naturally perceived as a threat to the capitalist mode of production and to the European community that formed the elite and were the owners of the means of production. So there were clear ideological differences which were bound to create mistrust between the socialist oriented nationalists and the capitalist settler farmers and industrialists. Was it not therefore, probable that the owners of the means of production would perceive the call to reconciliation as a ruse, at least in the early days? So the call to unity of purpose under the circumstances was met with scepticism by those who owned the means of production. One may argue that Mugabe was calling for mutual forgiveness and commitment to national reconciliation. Castigating any thought of reprisal against former oppressors, Mugabe proceeded to encourage people to do what he had done, drawing a line through the past and respond to his policy of reconciliation (Fuller, 2002). All this from a man who had been demonised as a Marxist dictator, almost likely to be an African Hitler was unbelievable. As pointed out by de Waal (1990) some Europeans actually fled Zimbabwe on the attainment of independence, others adopted a cautious wait and see attitude, while still others believed 
Mugabe was genuine in his call for reconciliation and were prepared to stay and accept the new reality of African majority rule.

Justice and reconciliation need to be inextricably linked, and it is unrealistic to ask victims and survivors of gross violations of human rights to reconcile in the absence of justice (Raftopoulos \& Savage, 2004). In Mawondo's (2009) reckoning, the policies of reconciliation pursued in Zimbabwe, Namibia and South Africa were without justice. The only country he points to, as having tried reconciliation with justice was Rwanda. He argues that in the first three countries it was reconciliation without justice because the policies "prevented an assault on inequality in wealth and income" (Mawondo, 2009, p. 5). In Zimbabwe, the land appropriated from the Africans remained with those who had unjustly acquired it during colonial subjugation. The legacy of economic inequalities characteristic of the colonial era when the majority of the people remained dispossessed and poor while a few people of European descent continued to wield economic power persisted after independence.

de Waal, (1990) reports that compared to about 1,000 Europeans who died during the liberation struggle, about 80,000 Africans perished either through being shot, poisoned, hanged, tortured or made to disappear by agents of the colonial regime, and approximately 450,000 Africans were wounded and many were displaced. It was these atrocities that Mugabe was calling upon the African majority to forgive and forget. Yet those who made war necessary in the first place through repudiating the principles of majority rule and one man one vote were blind to this reality the African had to live with, and therefore remained impervious to the reason why there was need for repentance and forgiveness. Inevitably, adopted under such an unjust background, the policy of national reconciliation, according to Mawondo, was without justice and according to van Binsbergen allowed the conflict to simmer on. Yet as Hapanyengwi-Chemhuru (2002) points out, among other things justice in Zimbabwe required a radical redistribution of land to the previously dispossessed, if reconciliation was to succeed. It would appear, therefore, that in the absence of an honest reappraisal of the real cause of what has become Chimurenga III among the land hungry Zimbabweans, the chances of reconciliation succeeding were compromised from the very beginning.

Siziba (2000) argues that reconciliation in Zimbabwe was bound to fail because the Europeans perceived the policy as a desperate attempt by a nationalist government to keep Europeans in this country at all costs. A sense of arrogant indispensability developed among the Europeans. It is in this context and in the context of the arguments raised above that Siziba proceeds, even further, to view reconciliation as a betrayal of the ideals of the liberation struggle. That some Europeans viewed reconciliation as a desperate measure to ensure their stay would explain why there was little effort on their part to reciprocate the policy of reconciliation.

In as far as relations between Africans and Europeans were concerned, the failure of National Reconciliation as a policy can be attributed to the fact that in 1980, the policy of National Reconciliation was enunciated and perceived as a necessity by those who perceived themselves as the victors. The underlying assumption was that the Europeans would be predisposed to accept the hand of reconciliation extended to them by the Africans. This was an assumption based on a false supposition, for it appears that the Europeans whom the Africans perceived as losers did not perceive themselves as such. Hence, they did not appreciate why they were obliged to accept and reciprocate the policy of national reconciliation. With the benefit of hindsight, it is now clear that this policy did not amount to more than well calculated rhetoric on the part of the new ZANU-PF administration to allay fears that the European population might have had at the time (Sachikonye, 2004). In fact de Waal (1990) argues that the former European settlers had little incentive to change since they continued to enjoy the upper-middle-class life style and they had financial resources and 
professional protection that remained remarkably secure. The new government had gone an extra mile at the Lancaster House Conference when it consented to racial representation in parliament for at least the first seven years after independence and that land was to be acquired only through the willing buyer willing seller principle. It was therefore logical that they should expect a similar response from the Europeans.

One can surmise that the Europeans did not appreciate the basis of the gesture of reconciliation. First and foremost, European informants heard that there would be no revenge or retribution. This early perception was encapsulated in comments that reconciliation meant 'let[ting] bygones be bygones', 'forgiveness', 'no witch-hunt', 'bringing people together', 'liv[ing] happily together' and 'we'll all be equal' (Fisher, 2010). Only a small number of Europeans were prepared to take stock of the past, and this was not encouraged in the early days by Mugabe as the architect of Zimbabwean reconciliation, beyond calls for their personal transformation in the interest of developing a new national identity (Alexander, 2004). However, most Europeans remained in their cocoon land and did not reciprocate the reconciliation gesture extended to them. This is confirmed by the fact that as early as 1985 the European electorate continued to vote for former Rhodesian Prime Minister, Ian Smith and his colleagues when they retained fifteen out of twenty ex-Rhodesian Front Member of Parliament. Smith himself the leader of the Rhodesian Front remained unrepentant as he refused to recognise the new government as a legitimate one. Some of the Europeans shared his vision; after all he had been their Prime Minister (de Waal, 1990).

It would appear the Europeans had no inclination to establish love and understanding between them and the Africans. Thus, reconciliation, as a liberal-pragmatic regime of truth (Sylvester, 2000), identified the minorities and co-opted them as potential nation builders despite indications of their ambivalent identification with the nationalist state (Fisher, 2010). In most cases, Europeans withdrew from all areas that they felt the Africans were infiltrating.

For Europeans, Mugabe's notion of personal transformation, of repudiating the colonial ethos, appeared harder to grasp, and the idea proved difficult to speak about, was glossed over and described as a vague philosophy that did not spell out specifically what was expected between races and ethnic groups in day-to-day living (Fischer, 2010). Yet, Mugabe addressing the United Nations Security Council in 1978 had argued, "We are not fighting European people but a racist regime." What this meant was that even if the racist regime crumbled and racism continued, genuine reconciliation was going to remain elusive, as the real impediment was racism. This is what some members of the European community in Zimbabwe failed to grasp. Consequently there was no genuine attempt to transform the conflict into reconciliation. The spirit of co-existence was simply not there among the European community. However, European liberals such as Denis Norman, David Smith and Chris Andersen who were included in the government of national unity accepted reconciliation as simply one of the terms of the peace settlement and credited the ruling elite with giving the European community 'a morale boost' in 1980 by including Europeans in the new government (Fisher, 2010).

\section{The Philosophy of Unhu/Ubuntu}

If the policy of National Reconciliation is to be resuscitated and be firmly grounded, there is need that all groups concerned attain the realisation of their common humanity. Commonality is a strong cultural, social, political and economic foundation to an African philosophy that is fundamental to community living (Shizha, 2009). There is need for a philosophical framework that respects the cultural diversity and the lived experiences of all people. In our context, the philosophy that comes to mind is the philosophy of unhu/Ubuntu (humanity, good behavior, respectful to others, pleasant and honest). Unhu forces us to come 
to terms with the fact that whether we are African, European, Shona, or Ndebele, tose tirivanhu (in spite of our racial or ethnic diversity the bottom line is that we are all human beings). We all need to live together. In Zimbabwe, community is an essential component social action and brings people together and imprints individuals with their social and cultural identity (Shizha, 2009). The philosophy of unhu is attractive for the values that it extols such as love for one another, respect for each other, brotherhood, and respect for the sacredness of human life.

The philosophy of unhu places premium on human life and promotes the dictum, Munhu munhu navanhu (ChiShona) or Umuntu ngumuntu ngabantu (IsiNdebele/IsiZulu) translated into, "I am because we are, and since we are, therefore I am" (Mbiti, 1987, p. 106). This aphorism enjoins us to recognize that, "we are human through recognising the humanity of others, and on that basis, establish humane relations with them" (Ramose, 1999, p. 52). Samkange and Samkange (1980, pp. 6-7) highlight three maxims of unhu/ubuntu that shape this philosophy: The first maxim asserts that "To be human is to affirm one's humanity by recognising the humanity of others and, on that basis, establish respectful human relations with others." The second maxim means that "If and when one is faced with a decisive choice between wealth and the preservation of the life of another human being, then one should opt for the preservation of life." The third maxim says "The king owed his status, including all the powers associated with it, to the will of the people under him." In other words, the maxims express the fundamental principle of interdependence and mutuality. According to Archbishop Desmond Tutu,

A person with Ubuntu is open and available to others, affirming of others, does not feel threatened that others are able and good, for he or she has a proper selfassurance that comes from knowing that he or she belongs in a greater whole and is diminished when others are humiliated or diminished, when others are tortured or oppressed. (Shizha, 2009, p. 143)

If we are informed by this philosophy, we are compelled to value human life and the mere fact of being human.

The philosophy of $u n h u$ further appeals to us because it cherishes values and attitudes that are already cherished by other cultures and are described as virtues. Such virtues include hospitality, fraternity, courtesy, self-sacrifice for the benefit of family and community, kindness, humility, consideration, gentleness, fairness, responsibility, honesty, justice, trustworthiness, hard work and integrity and above all tolerance. These are regarded as fundamental to being human. Thus to opt for unhu is to opt for the preservation of life. We also concur with Samkange and Samkange (1980, p. 34) when they argue, "Unhu/Ubuntu is, therefore, a philosophy that is the experience of thirty- five thousand years of living in Africa. It is a philosophy that sets a premium on human relations." We must promote the transition from a culture of imposition, force, violence and war to a culture of dialogue, conciliation, alliance, understanding and peace in human relations (Kotite, 2012).

\section{Education for Reconciliation through Unhu/Ubuntu}

If it is accepted that the philosophy of unhu can be the basis for reconciliation, it is then logical for education to play a fundamental role in the form of education for reconciliation. Education has the greatest potential to contribute towards the successful realisation of the policy of reconciliation. Conflict can impair the ability of governments to provide quality education for their citizens (Kotite, 2012). It is clear that education planning and resources are crucial even in the midst of conflict and during the initial humanitarian 
response and even where the initial emphasis is on physical reconstruction of the education system. Save the Children identifies four critical elements of quality education needed to support education's role in peace-building and conflict prevention; inclusive education and equal access to education, safety and protection of teachers and learners, appropriate curriculum and relevant educational materials, and schools that are accountable to children, parents and communities. The opinions of children, parents and the community must be sought and valued (International Save the Children Alliance, 2008). The relevance of these elements entail that education has a crucial role in post-conflict reconciliation in helping to raise awareness, promote understanding, contribute to reform, contribute to child protection, and support economic regeneration.

\section{Educating for Diversity}

The most realistic educational approach may be initiatives to build trust between former adversaries and communities; begin to document resources related to the conflict; and initiate pilot reconciliation projects in schools and youth and community groups (Smith, 2010). This is also a good time to explore opportunities to include reconciliation in formal education and the official curricula. Education reform takes time, and innovations are unlikely to be included unless they are part of the initial planning. Education for reconciliation aims at promoting multiculturalism and schools that are multicultural settings that reflect the process of reconciliation itself. Multicultural settings promote respect for and tolerance towards cultural diversity and an appreciation of cultural diversities without feeling threatened by the culture of the different other. Clearly education has a key role in dealing with the truth, telling and understanding what happened in the past; focus on addressing current needs, recovery from the legacies of conflict, and raising educational opportunities that have been missed (Smith, 2010). The teaching and learning process should also focus on the future aiming at contributing to reconciliation and sustainable, peaceful development.

\section{Teaching through Unhu}

Education for reconciliation through unhu reflects on the relationship between the concepts of reconciliation and unhu. It must be an education that fosters respect for the community and other individuals. Focus will therefore be on the good for the community. It will be an education that fosters those values that are enshrined in the philosophy of unhu. But how does education entrench or strengthen the values cherished in the philosophy of unhu? In Zimbabwe, schools should involve parents, learners, teachers and community members as a community of learners. Decisions on what and how students learn should not be the total responsibility of the government institutions and professional organisations that monopolize power and control, but the decision making process should be localised and be a down-top or horizontal process (Shizha, 2009). The teachers and parents have to be models for pupils; they have to be the epitome of vanhu vane unhu (individuals who value good behaviour). They should respect the pupils, treat them with care, fairness, tolerance and make pupils realize they are valued for who they are - human beings. Teachers must learn to work for the general good of the community, beginning with their school community. This can only be done through the development of a well-developed sense of identity that comes with one knowing one's history.

Munhu vanhu (A person is there because of other people) calls for interdependence and a realisation that individuals cannot exist alone but with and among others. So cooperation becomes crucial for the survival of the community. The school should therefore inculcate values that emphasise the oneness of humanity. Many factors will influence the role 
of education in reconciliation. One dimension is of sensitivity to context that relates to the social and cultural norms and behaviour that are appropriate or acceptable in dealing with past conflicts and their legacies (Smith, 2010). Educators may need to consider a range of factors in designing education, truth and reconciliation programmes. Some learners may have parents who participated in conflict situations in their community, or the learners themselves may have developed negativity towards those they were made to believe to be enemies. Therefore, unhu in the sense of togetherness has to be emphasised as the core of teaching and learning. Educators need to anticipate sensitivities and ethical issues that are likely to arise in dealing with such complexity and must have strategies for handling them. This reinforces the case for incorporating unhu into a planned, legitimised process managed by education officials, with intensive training for teachers and other educators. Education by its very nature contributes to shaping and transforming society and therefore plays a key role to peace building (Kotite, 2012).

\section{Reconstructing Education through Community Participation}

Unhu as a philosophy can be used in the reconstruction of education, particularly in terms of community participation in restoring the infrastructure in schools. As the Minister of Finance pointed out in his 2011 budget statement "rehabilitation and development of infrastructure remains an essential priority for supporting economic activity, thereby, consolidating the socio-economic recovery and growth agenda" (Biti, 2011, p. 130). While the minister's statement was directed at economic rehabilitation, the same can be said about rehabilitation of education and educational institutions. The reconstruction of the education system leads to economic recovery and therefore there is need to develop the infrastructure in schools and colleges. Community and parental involvement in this rehabilitation cannot be emphasised. According to Te Aika and Greenwood (2009), the relationship between project goals and participants is important in implementing projects. Community partnerships, which in essence, are fundamental to the philosophy of $u n h u$, are a pivotal factor in the design and implementation of school infrastructural projects. Rebuilding or repainting schools and supplying schools with furniture will go a long way in restoring the quality of learning in Zimbabwe.

Participation in revitalising the education system provides communities with the power of ownership of their schools. Not only does participation provides communities with ownership, but they will also gain social power. The satisfaction that participants will get from being identified with the improved infrastructure in their schools will bring about unity in the community. There is social satisfaction and social cohesion when persons have the opportunities to be "doers and actors" (Young, 1990, p. 37) in social arenas that are meaningful to them (Chambers \& Balanoff, 2009). According to Young (1990), socially just participation involves:

Learning and using satisfying and expansive skills in socially recognised settings; participating in forming and running institutions, and receiving recognition for such participation; playing and communicating with others, and expressing our experiences, feelings, and perspectives on social life in contexts where others can listen. (p. 37)

Rural people in Zimbabwe have been utilising participation as a tool for development from time immemorial. Therefore, collectivism and unhu/ubuntu are typically suited to reconstruction of school infrastructure to restore the education system in Zimbabwe (Shizha, 2009). Collectivism and participation provides or reinforces the power of community living 
and people can exercise their agency together as a group and at the same time displaying various abilities (Mhina, 2009) and skills in solving their community problems. Decaying infrastructure in schools is a community problem that requires community solutions. Consequently, communities should take collective steps, mobilize their unhu/ubuntu mentalities and make collective decisions to rehabilitate their schools for the sake of their children's education.

\section{Conclusion}

It has been argued in this paper that genuine reconciliation in Zimbabwe failed because there was no shared vision between the 'victors' and the 'defeated'. Furthermore, those who were defeated did not appreciate the policy of reconciliation. Among Africans, the policy of reconciliation was selectively applied. Given these weaknesses, the policy of reconciliation was bound to fail. We then proposed revisiting the policy of reconciliation but now grounded in the philosophy of $u n h u$ which places premium on human life. But to ensure that this reconciliation founded upon $u n h u$ takes root, the education system must be roped in to facilitate the inculcation of values enshrined in unhu. Schools should implement the philosophy of unhu in their planning, curriculum and pedagogy. The success of these approaches ultimately depends on local commitment, but the government and nongovernmental organisations can play a role in supporting local initiatives during a period when truth recovery and reconciliation are needed to be a priority in national building.

The Government of Zimbabwe should use education must foster sustainable development and active and effective global and local citizenship, as well as contribute to strengthening democracy, dialogue, mutual understanding and the peaceful resolution of conflict, while preventing the promotion of all forms of extremism and violence. This is particularly important in conflict and post-conflict situations. Policy-makers, youth, women, and the media have an important role to play in maintaining and restoring peace as part of a holistic vision of education. It is imperative for teachers to employ pedagogy for peace to cultivate a culture of peace in the country. In conclusion, peace education as a practice aims to confront and resist violence to transform societies toward reconciliation, social harmony and toward building cultures of peace. Peace education focuses both on education about peace and education for peace while addressing the knowledge, values, skills and behaviours needed to nurture a peace culture (Kester, 2009). 


\section{References}

Alexander, K. (2004). Orphans of the empire. An analysis of elements of European identity and ideology construction in Zimbabwe. In B. Raftopoulos \& T. Savage (Eds.), Zimbabwe injustice and political reconciliation (pp. 193-212). Cape Town: Institute for Justice and Reconciliation.

Biti, T. (2011). The 2011 national budget statement: Shared economy, shared development, shared transformation. Harare: Ministry of Finance/Government of Zimbabwe.

Chambers, C., \& Balanoff, H. (2009). Translating "participation" from North to South: A case against intellectual imperialism in social science research. In D. Kapoor \& S. Jordan (Eds.), Education, participatory action research, and social change: International perspectives (pp. 73-88). New York: Palgrave Macmillan.

de Waal, V. (1990). The politics of reconciliation: Zimbabwe's first decade. Cape Town: Hurst \& Company.

Fisher, J. (2010). Pioneers, settlers, aliens, exiles: The decolonisation of European identity in Zimbabwe. Canberra: The Australian National University.

Fuller, A. (2002, August, 15). The bitter harvest. The Guardian. Retrieved July 17, 2012 from: www.guardian.co.uk/print/0,3858,44 81955-103677,00.html)

Graybill, L. (2002). Truth and reconciliation in South Africa: Miracle or model? Boulder: Lynne Rienner.

Hapanyengwi-Chemhuru, O. (2002). Justice and the land question: The historical experience of Zimbabwe. Journal of Peace, Conflict and Military Studies, 2(1), 29-40.

Huyse, L. (2005). Reconciliation: Theory and practice. In G. Kelly \& B. Hamber (Eds.), Reconciliation. Rhetoric or relevant? (pp.7-13). Belfast: Democratic Dialogue.

International Save the Children Alliance (2008). Where peace begins. Education's role in conflict prevention and peace building. London: International Save the Children Alliance.

Institute for Democracy and Electoral Assistance (IDEA) (2003). Reconciliation after violent conflict. Retrieved August 14, 2012 from:

http://www.idea.int/publications/reconciliation/upload/reconciliationfull.pdf

Kester, K. (2009). Education for peace: Content, form, and structure: Mobilising youth for civic engagement. Paper presented at the World Civic Forum in Seoul, South Korea, May 5-8, 2009.

Kotite, P. (2012). Education for conflict prevention and peacebuilding: Meeting the global challenge of the 21st century. IIEP Occasional Paper, Paris: UNESCO.

Loizides, N., Kovras, I. \& Ireton, K. (2011). Introduction: federalism, reconciliation, and power-sharing in post-conflict societies. Federal Governance: A Graduate Journal, $8(2), 1-8$.

Machakanja, P. (2010). National healing and reconciliation in Zimbabwe: Challenges and opportunities. Zimbabwe Monograph Series No. 1/2010. Wynberg: Institute for Justice and Reconciliation.

Mawondo, S. (2009). In search of social justice: Reconciliation and the land question in Zimbabwe. Retrieved February 27, 2011 from: http://www.crvp.org/book /series02/II12/ chapter-1.htm

Mhina, C. (2009). Research and agency: The case of rural women and land tenure in Tanzania. In D. Kapoor \& S. Jordan (Eds.), Education, participatory action research, and social change: International perspectives (pp. 155-168). New York: Palgrave Macmillan.

Raftopoulos, B. (2004). Introduction: Unreconciled differences, the limits of reconciliation politics in Zimbabwe. In B. Raftopoulos, \& T. Savage, (Eds.), Zimbabwe: Injustice and 
political reconciliation (pp. viii-xxii). Cape Town: Institute for Justice and Reconciliation.

Raftopoulos, B. \& Savage, T. (Eds.) (2004). Zimbabwe: Injustice and political reconciliation. Cape Town: Institute for Justice and Reconciliation.

Ramose, M. (1999). African philosophy through ubuntu. Harare: Mond Books.

Sachikonye, L. (2004). The promised land: From expropriation to reconciliation and jambanja. In B. Raftopoulos, \& T. Savage (Eds.), Zimbabwe: Injustice and political reconciliation (pp. 1-18). Cape Town: Institute for Justice and Reconciliation.

Samkange, T. \& Samkange, S. (1980). Unhuism or ubuntuism: A Zimbabwe indigenous political philosophy. Salisbury (Harare): Graham Publishing.

Shizha, E. (2009). Chara chimwe hachitswanyi inda: Indigenising science education in Zimbabwe. In D. Kapoor \& S. Jordan (Eds.), Education, participatory action research, and social change: International perspectives (pp. 139-154). New York: Palgrave Macmillan.

Siziba, N. (2000). Reconciliation in Zimbabwe not so smart after all. The Zimbabwe Mirror, Friday 10 November.

Smith, A. (2010). Children, education and reconciliation, Innocenti Working Paper No. 201010. Florence: UNICEF Innocenti Research Centre.

Sylvester, C. (2000). Producing women and progress in Zimbabwe. Portsmouth: Heinemann.

Te Aika, L-H. \& Greenwood, J. (2009). Ko tōtou te rangahau, ko te rangahau, ko tōtou: A Mōori approach to participatory action research. In D. Kapoor \& S. Jordan (Eds.), Education, participatory action research, and social change: International perspectives (pp. 59-72). New York: Palgrave Macmillan.

Thoms, O., Ron, J. \& Paris, R. (2008). The effects of transitional justice mechanisms: A summary of empirical research findings and implications for analysts and practitioners. Ottawa: Centre for International Policy Studies.

van Binsbergen, W. (1999). Reconciliation: A major African social technology of shared and recognised humanity (ubuntu). Retrieved December 31, 2011 from: http://www.shikanda.net/general/gen3.invo eg15_mei_99/reconcil.htm

Young, I. (1990). Justice and the politics of difference. Princeton: Princeton University Press. 